\title{
PROFILE OF OPEN-ENDED PROBLEM SOLVING BASED ON POLYA'S STEPS VIEWED FROM MATHEMATICAL ABILITY LEVEL OF JUNIOR HIGH SCHOOL STUDENTS
}

\author{
Safirah Viki Amalina \\ Mathematics Education, Mathematics and Natural Sciences Faculty, State University of Surabaya \\ Email: safirahamalina16030174068@mhs.unesa.ac.id \\ Rooselyna Ekawati \\ Mathematics Education, Mathematics and Natural Sciences Faculty, State University of Surabaya \\ Email: rooselynaekawati@unesa.ac.id
}

\begin{abstract}
Problem solving is one of several important abilities a student must have. Problem solving is a planned process that must be done in order to get a certain solution of a problem that is not obtained immediately. One type of problem students must solve is an open-ended problem. Open-ended problem solving for every student is certainly different from one another. The level of mathematical ability of students is one of the factors that influence these differences. This type of research is a qualitative descriptive with the purpose to describe the profile of open-ended problem solving based on Polya's steps viewed from mathematical ability level of junior high school students. Three students from grade VII are the subjects in this research (one student having high mathematical ability, one student having moderate mathematical ability, and one student having low mathematical ability). This research uses instruments mathematical ability test, openended problem solving test, and interview guidelines. The results showed there were differences in the open-ended problem solving profile on students with high, moderate, and low mathematical ability. Student with high mathematical ability can carry out all the steps of Polya's problem solving. Student with moderate mathematical ability are able to carry out the step of understanding the problem, devising a plan, carrying out the plan, however there are indicators that are not fulfilled at looking back's step they are using the other way to solve the problem and make conclusion. Student with low mathematical ability can not show the adequacy of the data at understanding the problem's step and can not carry out the steps of devising a plan, carrying out the plan and looking back.
\end{abstract}

Keywords: problem solving, open-ended problems, Polya's steps, mathematical ability.

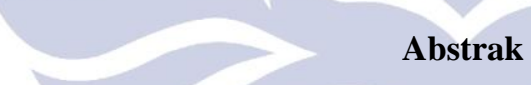

Pemecahan masalah adalah satu dari beberapa kemampuan penting yang harus dimiliki oleh siswa. Pemecahan masalah merupakan proses terencana yang harus dilakukan agar mendapatkan penyelesaian tertentu dari sebuah masalah yang tidak didapat dengan segera. Salah satu jenis masalah yang harus dipecahkan siswa adalah masalah open-ended. Pemecahan masalah open-ended setiap siswa tentu berbeda antara satu dengan yang lain. Tingkat kemampuan matematika siswa menjadi salah satu faktor yang mempengaruhi perbedaan tersebut. Jenis penelitian ini adalah penelitian deskriptif kualitatif dengan tujuan untuk mendeskripsikan profil pemecahan masalah open-ended berdasarkan langkah Polya ditinjau dari tingkat kemampuan matematika siswa SMP. Tiga siswa kelas VII merupakan subjek dalam penelitian ini (satu siswa memiliki kemampuan matematika tinggi, satu siswa memiliki kemampuan matematika sedang, dan satu siswa memiliki kemampuan matematika rendah). Penelitian ini menggunakan instrumen berupa Tes Kemampuan Matematika (TKM), Tes Pemecahan Masalah Open-Ended (TPMOE), dan pedoman wawancara. Hasil penelitian menunjukkan terdapat perbedaan profil pemecahan masalah open-ended siswa berkemampuan matematika tinggi, sedang, dan rendah. Siswa yang memiliki kemampuan matematika tinggi dapat melaksanakan semua tahap pemecahan masalah Polya. Siswa yang memiliki kemampuan matematika sedang dapat melaksanakan tahap memahami masalah, merencanakan penyelesaian, melaksanakan rencana penyelesaian, namun terdapat indikator yang tidak terpenuhi pada tahap memeriksa kembali yaitu menggunakan cara lain untuk menyelesaikan masalah dan membuat kesimpulan. Siswa yang memiliki kemampuan matematika rendah tidak dapat menunjukkan kecukupan data pada tahap memahami masalah serta tidak dapat melaksanakan tahap merencakan penyelesaian, melaksanakan rencana penyelesaian dan memeriksa kembali.

Kata kunci: pemecahan masalah, masalah open-ended, langkah Polya, kemampuan matematika. 


\section{INTRODUCTION}

Mathematics learning is a planned process with various activities provided to students to be able to understand the mathematics material being studied (Muhsetyo, 2008). In order to achieve these goals properly, mathematics learning needs to be given special attention. As for one of the goals of learning mathematics expressed by As'ari, et al (2017) is solving problems in everyday life (the real world).

Permendikbud No.21 of 2016 concerning Basic and Secondary Education Content Standards states that "one of the competencies students must have through learning mathematics is students can show a logical, critical, analytical, careful and thorough, responsible, responsive, and not easily give up attitude in solving problems". Likewise, the purpose of learning mathematics according to the National Council of Teachers of Mathematics or NCTM (2000) about the five basic abilities that students need to master, namely communication, reasoning and proof, problem solving, connection and representation. According to As'ari, et al (2017), NCTM (2000) and Permendikbud No.21 of 2016 concerning Basic and Secondary Education Content Standards, it appears that problem solving is one of the important factors students must have.

Ozturk and Guven (2016) stated that problem solving is a procedure carried out by someone to solve a problem that starts with digesting the given problem followed by exploring the facts and explanations needed then looking for a way out of the problem accompanied by several considerations. In fact, students in Indonesia are still low in their ability to solve mathematical problems. This is shown by the results of the analysis of Trends in International Mathematics and Science Study (TIMSS) and the Program for International Student Assessment (PISA) in which one type of TIMSS and PISA questions is related to problem solving. Based on the results of the TIMSS study conducted in 2015, Indonesian students received an average score of 397 and ranked 44th out of 49 countries. Meanwhile, in 2015 the results of the PISA analysis stated that the average math score obtained by Indonesian students was 386 and occupy 63 positions from 70 countries (OECD, 2018).

The results of the two international studies above can be a reference to the mathematics learning process that occurs in the field. As for one of the factors that influence the level of problem solving of students is the problem given by the teacher. Hudojo (1988) said that the question would be categorized as a problem if someone could not directly use the method or law to get an answer. Wahyudi, et al (2012) categorize mathematical problems into two types, namely open-ended problems and closed problems. A closed problem has only one correct answer while an open problem has several correct answers or several ways to get the correct answer (Shimada, 2007). Furthermore, Foong (2002) stated that the structure of open-ended problems is incomplete and there are no permanent steps to guarantee the correct solution.

Learning mathematics in class so far often uses closed problems which are only fixated on one correct answer so students feel difficulties when facing open problems. Provision of closed problems also impacts the lack of student creativity in solving mathematical problems. Furthermore, Russeffendi (in Emilya, 2010) said to express or encompass creative people should use open-ended problems. Based on research conducted by Purnamasari (2015), said that students are only able to do one step in solving open-ended problems, that is understanding a problem.

To solve an open-ended problem requires a procedure or steps. Polya (2004) introduces models, procedures or problem solving steps, namely understanding the problem, devising a plan, carrying out the plan and looking back.

There are various factors that can affect students' problem solving abilities including gender differences, self efficacy, cognitive style differences, emotional intelligence, and the level of mathematical ability. One of the factors that influence is the level of mathematical ability. Each student has different mathematical abilities. This is in line with Syaban's opinion (in Febriana, 2013) which divides the level of students' mathematical abilities into three namely high, moderate, and low.

One of the level that can be the target of research to solve open-ended problems with different levels of mathematical ability is the junior high school. Junior high school students ( 11 years-adults) are at the formal operational stage based on Piaget's theory of cognitive development, where at this stage students are able to think abstractly, that is, able to solve problems despite the absence of real objects and think of some alternative solutions to the problem.

Q This research is relevant to the research entitled "Open-Ended Problem Solving Profile of Students with STJ and NFJ Personalities on Count Average Material" which aims to describe the profile of open-ended problem solving on centralizing data size material based on the personality type of the MBTI students. Both of these researchs have in common that they both use a qualitative approach to the profile of open-ended problem solving, it's just different in the reviews and research subjects. That research uses a review based on the personality types of students namely STJ (Sensing-Thinking-Judging) and NFJ (Intuition-Feeling-Judging) and uses subjects grade VIII, while in this research uses a review of students' 
mathematical ability levels of high, moderate, and low and use grade VII of junior high school as research subject.

Based on the explanation above, this research aims to describe the profile of open-ended problem solving based on Polya's steps viewed from mathematical ability of junior high school students.

\section{METHOD}

This type of research is a qualitative descriptive research with the aim of describing the profile of open-ended problem solving based on Polya's steps viewed from mathematical ability level of junior high school students. The subjects in this research consisted of three students: one student had high mathematical ability, one student had moderate mathematical ability, and one student had low mathematical ability.

The research instrument is the researcher herself as the main instrument and supporting instruments namely the mathematics ability test, open-ended problem Solving test, and interview guidelines. There are 5 questions that were tested in the mathematics ability test which were adapted from the student mathematics book, whereas in the open-ended problem solving test using rectangular and triangular material that consisting of 1 question. In this research, the data obtained are the results of open-ended problem solving tests and interview data. Open-ended problem solving tests are carried out by selected subjects and then interviews are conducted with the aim to explore information that has not been seen through an open-ended problem solving written test.

In this research there are three types of data analysis, namely data analysis on mathematical ability test results, data analysis of open-ended problem solving test results, and data analysis of interview results. Data analysis of mathematical ability test results is done by grouping student scores into three categories: high, moderate, and low. In this research, the grouping of students' mathematical abilities was determined based on MCC (Minimum Completeness Criteria), while the score interval at the level of mathematical ability was as follows.

Table 1. Category of Mathematical Ability

\begin{tabular}{|l|l|}
\hline \multicolumn{1}{|c|}{ Category } & \multicolumn{1}{c|}{ Score } \\
\hline High & $86-100$ \\
\hline Moderate & $70-85$ \\
\hline Low & $0-69$ \\
\hline
\end{tabular}

(Panduan Penilaian oleh Pendidik dan Satuan Pendidikan untuk Sekolah Menengah Pertama, 2017)

Data analysis of the results of open-ended problem solving tests was analyzed based on Polya's problem solving indicators.
Table 2. Indicators of Open-Ended Problem Solving

\begin{tabular}{|c|c|}
\hline Ability & Indicators \\
\hline $\begin{array}{l}\text { 1. Understanding } \\
\text { the problem }\end{array}$ & $\begin{array}{l}\text { a. Mention all things that are } \\
\text { known (1a) } \\
\text { b. Mention all things that are asked } \\
\text { (1b) } \\
\text { c. Show enough, less or excessive } \\
\text { related things that are known to } \\
\text { solve the problem (1c) }\end{array}$ \\
\hline $\begin{array}{l}\text { 2. Devising } \\
\text { plan }\end{array}$ & $\begin{array}{l}\text { a. Make plans and concepts that } \\
\text { will be used to solve problems } \\
\text { (2a) }\end{array}$ \\
\hline 3. Carrying out & $\begin{array}{l}\text { a. Carry out calculations in } \\
\text { accordance with the settlement } \\
\text { plan that has been made ( } 3 a) \\
\text { b. Explain the problem solving } \\
\text { strategy in a structured way with } \\
\text { clear and logical reasons (3b) }\end{array}$ \\
\hline 4. Looking back & $\begin{array}{l}\text { a. Re-check the results obtained } \\
(4 a) \\
\text { b. Use other ways to solve the } \\
\text { problem (4b) } \\
\text { c. Make conclusions (4c) }\end{array}$ \\
\hline
\end{tabular}

Data analysis of the results of the interview refers to the stage of Miles \& Huberman (2014), namely the stage of data reduction, data presentation, and drawing conclusions.

\section{RESULT AND DISCUSSION}

Open-ended problems that are tested on research subjects as follows.

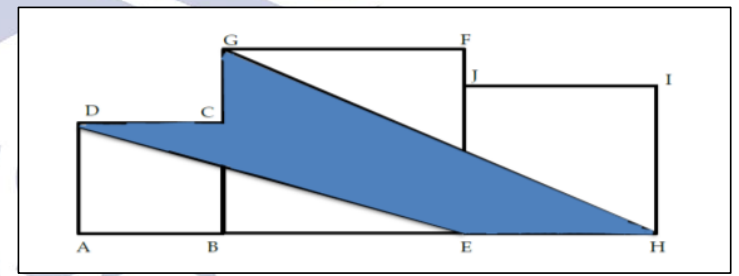

Three squares in a row measuring $6 \mathrm{~cm}, 10 \mathrm{~cm}$ and $8 \mathrm{~cm}$ respectively. Determine the area of shaded region!

(Do the problem at least using two ways)

The details of the selected subjects from each category of mathematical ability level are presented in the following table.

Table 3. Research Subject

\begin{tabular}{|c|c|c|}
\hline Subject Code & Category & Score \\
\hline S1 & High & 88 \\
\hline S2 & Moderate & 71 \\
\hline S3 & Low & 8 \\
\hline
\end{tabular}

Based on the analysis results of open-ended problem solving tests and analysis of interviews of student with high mathematical ability (S1), student with moderate mathematical ability (S2), and student with low 
mathematical ability (S3), so the results of the description of open-ended problem solving profiles based on Polya's steps viewed from mathematics ability level of junior high school students as follows.

\section{Profile of Open-Ended Problem Solving on High Mathematical Ability Student}

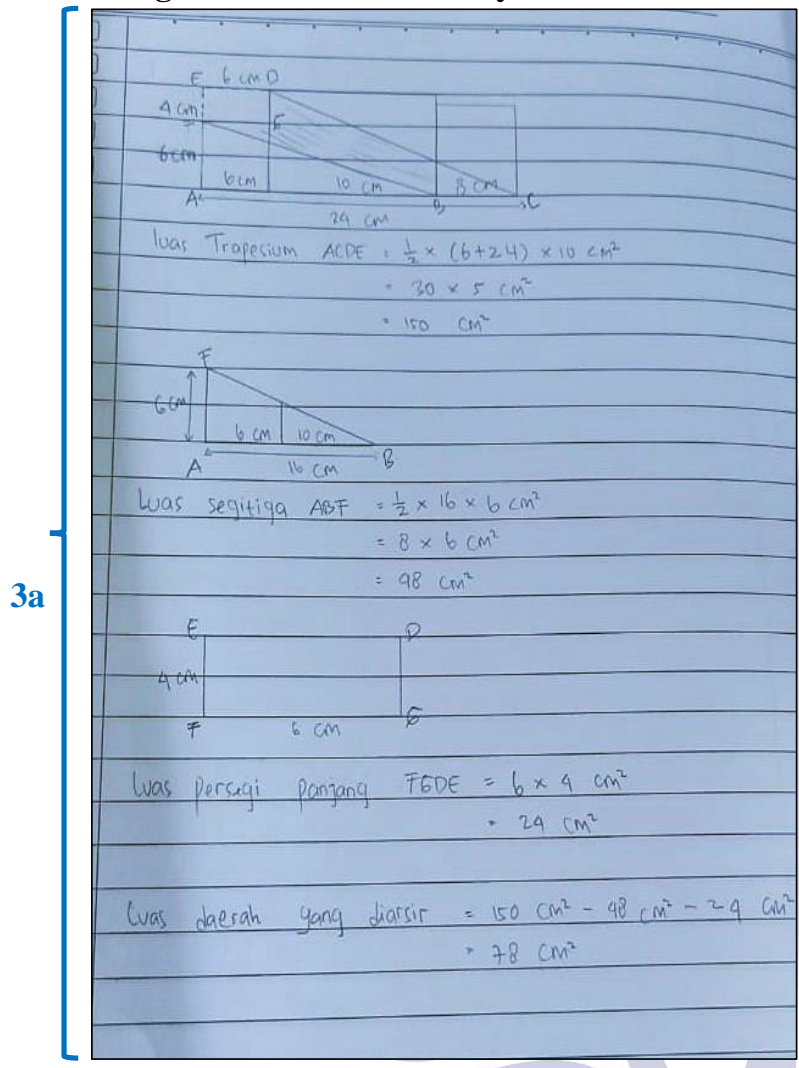

Figure 1. Results of written answers from $\mathrm{S} 1$

In the step of understanding the problem, $\mathrm{S} 1$ does not write the things that are known and asked of the problem given as shown in Figure 1. However, S1 can explain in words about what is understood from the problem, information that is known and things asked of the problem given. This can be shown as an interview between researcher (R) with $\mathrm{S} 1$ as follows.

$\mathrm{R}$ : Do you understand the problem given?

S1 : Little understand.

$\mathrm{R}$ : Please tell me what the problem is like?

S1 : So, there are three squares. The first square measures $6 \mathrm{~cm}$, the second square measures $10 \mathrm{~cm}$, and the third square measures $8 \mathrm{~cm}$. Then, ordered to calculate the area of shaded region.

1a $\begin{cases}\mathrm{R} & : \text { What things are known from the } \\ & \text { problem? } \\ \mathrm{S} 1 \quad: & \text { There are three. The length of the first }\end{cases}$ square is $6 \mathrm{~cm}$, the length of the second square is $10 \mathrm{~cm}$, the length of the third square is $8 \mathrm{~cm}$.

$1 \mathrm{~b}\{\mathrm{R}:$ Then, what was asked?

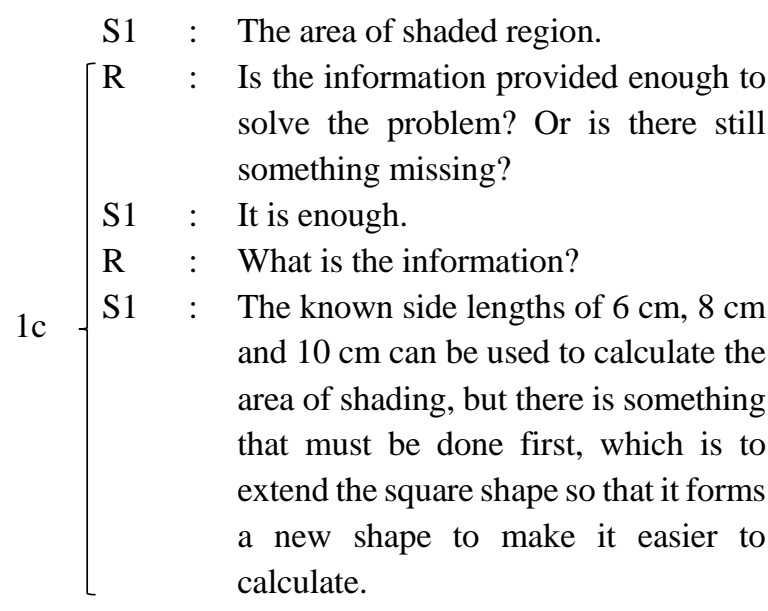

Based on the interview excerpt above, S1 understands the problem given. S1 tells the problem using the sentence itself. S1 also mentions exactly what is known, namely the length of the first square side is $6 \mathrm{~cm}$, the length of the second square side is 10 $\mathrm{cm}$, and the length of the third square side is $8 \mathrm{~cm}$ and mentions the question asked, namely the area of the shaded region. S1 also understands the adequacy of the data that things that are known to the problem are enough to be used to work on the given problem.

After the step of understanding the problem, the second step is devising a plan. As shown in Figure 1, first is calculating the area of the trapezoid, then calculating the area of the triangle, and then calculating the area of the rectangle. It can be seen that $\mathrm{S} 1$ can arrange plans, for more details, look at the following interview excerpt.

$\mathrm{R} \quad$ : Have you ever worked on a problem like this before?

S1 : Yes. Ever before.

$\mathrm{R}$ : What is your idea to solve this problem?

S1 : First, I extend the first square shape so that the first and second square shapes when combined will become rectangular shapes.

R : why did you do that?

$2 \mathrm{a}$

S1 : To make it easier to find the area.

$\mathrm{R}$ : Then, what is the next step?

S1 : I calculated the area of the trapezoid, the area of the triangle, and the area of the rectangle.

$\mathrm{R}$ : Then, how to calculate the shaded area?

S1 : By subtracting all of them.

$\mathrm{R}$ : What do you mean?

S1 : The area of the trapezoid subtract with $2 \mathrm{a}-$ the area of the triangle subtract with the area of the rectangle. 
$\mathrm{R}$ : Was your settlement plan like this from the beginning?

S1 : Yes, my plan from the beginning was like this.

The third step is carrying out the plan. Based on the plan or steps that have been prepared by $\mathrm{S} 1$, then $\mathrm{S} 1$ can carry out the completion plan as in Figure 1. The researcher also explore information through interviews as follows.

$\mathrm{R}$ : In answering the problem given, is it in accordance with the steps that you have planned?

S1 : Yes. It is.

$\mathrm{R}$ : Try to explain how you solved this problem?

S1 : First, I calculated the area of a right trapezoid using the formula half times the number of parallel pairs times the height of the trapezoid. And the result is $150 \mathrm{~cm}^{2}$.

$\mathrm{R}$ : How did you know that trapezoid height is 10 ?

S1 : From the length of the second side of the square. The height of the trapezoid is the same as the length of the second square.

$\mathrm{R}$ : Yes, true. Then, where did 24 come from?

S1 : Add all of them. 6 plus 10 plus 8 is 24 .

$\mathrm{R}$ : What is the next step?

S1 : Calculate the area of a triangle, the result is $48 \mathrm{~cm}^{2}$. Then calculate the area of the top rectangle, $6 \mathrm{~cm}$ in length and $4 \mathrm{~cm}$ in width obtained from $10 \mathrm{~cm}$ minus $6 \mathrm{~cm}$. The result is $24 \mathrm{~cm}^{2}$.

$\mathrm{R}$ : After calculating the area of the trapezoid, the area of the triangle and the area of the rectangle, then how do you calculate the shaded area?

S1 : The way is the area of the trapezoid minus the area of the triangle minus the area of the rectangle.

$\mathrm{R}$ : What is the result?

$-S 1: 78 \mathrm{~cm}^{2}$.

The fourth step is looking back. At this step, S1 can re-check the answer and believe that the answer is correct. $\mathrm{S} 1$ also works on these problems using other way and answers the conclusions of the given problem. This is shown in the following interview excerpt.

$\left[\begin{array}{ll}\mathrm{R}: \text { Are you sure that the steps are all } \\ \text { right? } \\ \mathrm{S} 1 \quad: \text { Yes. I am sure. }\end{array}\right.$

$\mathrm{R}$ : Before being collected, has the answer been checked again?

$4 \mathrm{a}$

S1 : Yes. It has.

$\mathrm{R}$ : Why does it need to be checked again?

S1 : So if there is something wrong, we know, so we can correct it.

$\mathrm{R}$ : Now, did you find a different way to do this problem?

S1 : Wait.

$\mathrm{R}$ : Try to think again!

S1 : Yes. There is other way.

$\mathrm{R}$ : How is the way?Try writing it down!

S1 write other way as shown below.

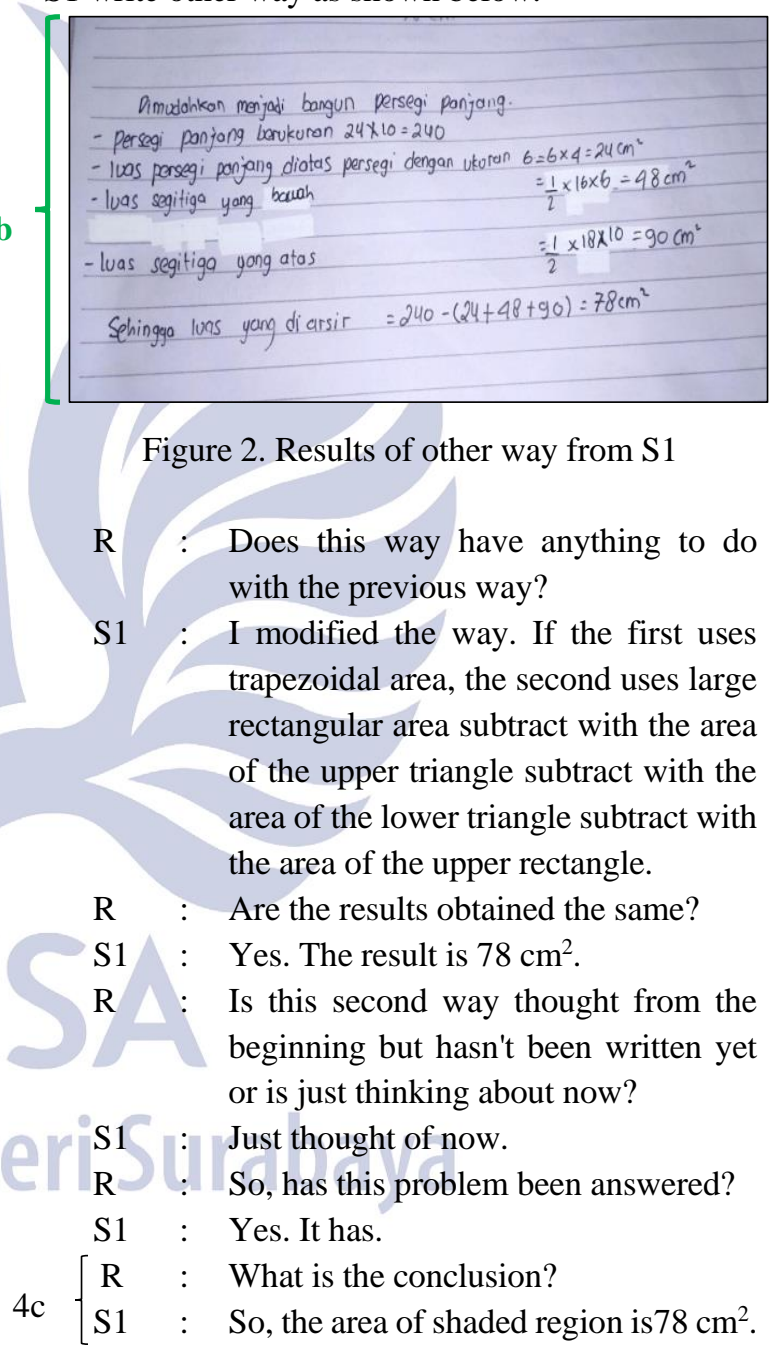

2. Profile of Open-Ended Problem Solving on Moderate Mathematical Ability Student 


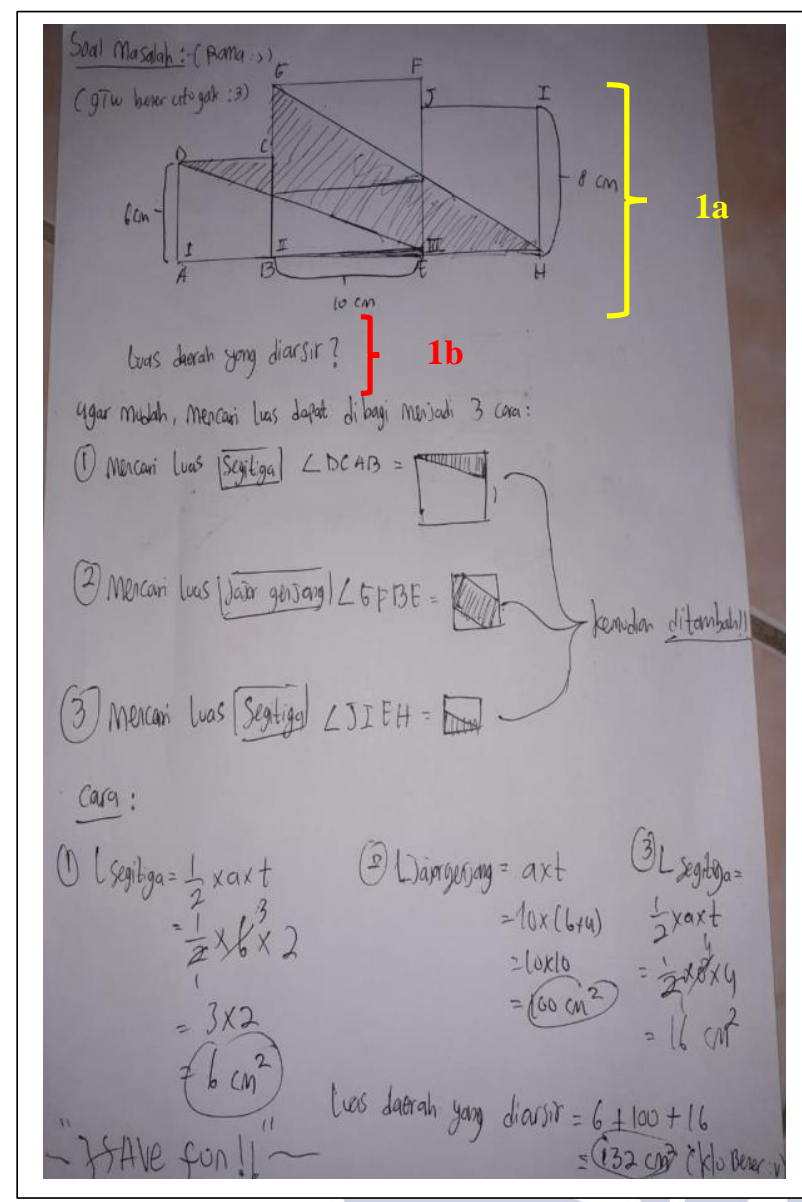

Figure 3. Results of written answers from S2

In the step of understanding the problem, S2 writes things that are known through the drawings made. Students also write down what is asked of the problem. For more details, researcher explores information through interviews as follows.

$\mathrm{R} \quad$ : Do you understand the problem given?

S2 : Yes.

$\mathrm{R}$ : Please tell me what the problem is like?

S2 : So, there are three squares. The first square has a side length of $6 \mathrm{~cm}$, the second square has a side length of 10 $\mathrm{cm}$, while the third square has a side length of $8 \mathrm{~cm}$.

$1 \mathrm{~b}\left\{\begin{array}{lll}\mathrm{R} & : & \text { Then, what was asked? } \\ \mathrm{S} 2 & : & \text { The area of shaded region. }\end{array}\right.$

[ $\mathrm{R}$ : Is the information provided enough to solve the problem? Or is there still something missing?

S2 : Enough.

$1 \mathrm{c}$ : What is the information?

S2 : Things that are known, namely the length of the three sides of a square, respectively $6 \mathrm{~cm}, 8 \mathrm{~cm}$, and $10 \mathrm{~cm}$ can be used to work on the problem.
Based on interviews conducted by researcher on S2, it appears that S2 can understand the problem. S2 can retell what is understood from the problem using the sentence itself. S2 also shows the adequacy of the data that things that are known from the problem are enough used to work on the problem.

The second step is devising a plan. S2 writes the completion plan as shown in Figure 3. S2 calculates the shaded area by dividing the structure into 3 parts to make it easier to calculate. First, S2 calculates the area of the upper triangle. Second, calculate the area of parallelogram. Third, calculate the area of the bottom triangle. However, S2 made a mistake, that is in the second plane, because it was not a parallelogram. For more details, researcher explore information through the following interview.

$\mathrm{R}$ : What is your idea to work on this problem?

S2 : To make it easier, I divide into three parts. The first to find the area of the upper triangle, the second to find the area of the parallelogram, the third to find the area of the lower triangle.

$\mathrm{R}$ : Is the first and the second plane a triangle?

S2 : Yes.

R : First, where is the height of the triangle $2 \mathrm{~cm}$ obtained from?

S2 : I guess.

$\mathrm{R}$ So, you also guess the height of the third triangle?

S2 Yes.

$\mathrm{R} \quad$ Is the guessing the result always right?

S2 Not always.

$\mathrm{R}$ : Can you calculate it?

S2 : I Can not, because the length of the hypotenuse is unknown.

$\mathrm{R}$ : Then, is the second plane a parallelogram?

S2 : Yes.

$\mathrm{R}$ : Are you sure?

S2 : Yes, I am sure.

$\mathrm{R}$ : What are the characteristics of parallelogram?

S2 : Has two folding symmetries and rotary symmetries.

$\mathrm{R}$ : What else?

S2 : Has two pairs of equal angles.

$\mathrm{R}$ : Right, then what else?

S2 : Has two pairs of edges.

$\mathrm{R}$ : What is the condition for the edges?

S2 : Must be parallel.

$\mathrm{R} \quad$ : What is the meaning of parallel? 
If the line is extended the lines do not intersect.

$\mathrm{R}$ : You are right. Now try to extend the lines, intersect or not?

S2 : Have done. The lines are intersect.

$\mathrm{R} \quad$ : So, it is parallel or not?

$\mathrm{S} 2:$ No.

$\mathrm{R} \quad$ : If it is not parallel, Does it still called parallelogram?

S2 : No.

$\mathrm{R}$ : Does that mean you already know that the second one is not parallelogram?

S2 : Yes, I already know.

$\mathrm{R}$ : If you already know that the second plane is not parallelogram, now try to think of using other way that you think are easier.

\section{S2 : I can not.}

Based on interviews that have been done, S2 has an error on the second plane. S2 says that the second plane is a parallelogram. Researcher explores information about the characteristics of parallelogram and student are able to explain it. S2 is not careful so there is an error in the answer sheet. But after the interview, students have realized their mistakes.

Researcher try to provide stimulation to student by giving similar questions but the level is easier. The question given by researcher is as follows.

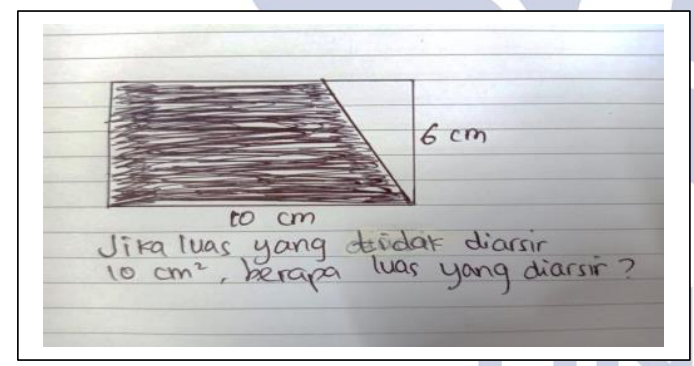

Figure 4. First stimulation problem

$\mathrm{R}$ : How do you calculate the shaded area? S2 : Still confused.

$\mathrm{R}$ : The rectangle is composed of several shapes, there are trapezoid and triangle. How to calculate the shaded area?

S2 : By subtracting.

$\mathrm{R} \quad$ : What do you mean?

S2 : The area of the rectangle minus the area of the shaded trapezoid.

$\mathrm{R}$ : Yes, true. Now back to the first problem, how do you calculate the area of shaded region?

S2 : I am still confused.

Researcher again provide $\mathrm{S} 2$ stimulus by giving a similar problem. The question given by researcher is as follows.

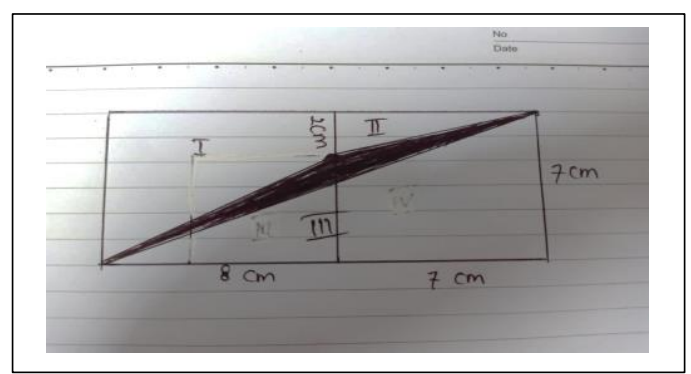

Figure 5. Second stimulation problem

$\mathrm{R}$ : Now, if there are problems like that, how do you calculate the shaded area?

S2 : I don't know.

$\mathrm{R}$ : Same with the previous one, rectangle is composed of several shapes. Try to mention it!

S2 : Trapezoid, upper triangle, shaded triangle, and the bottom triangle.

R : How do you calculate the area of a shaded triangle?

S2 : The area of the rectangle minus the area of the trapezoid minus the area of the upper triangle minus the area of the bottom triangle.

R : Yes, you are right.

Researcher again provide $\mathrm{S} 2$ stimulus by giving a similar problem. The question given by researcher is as follows.

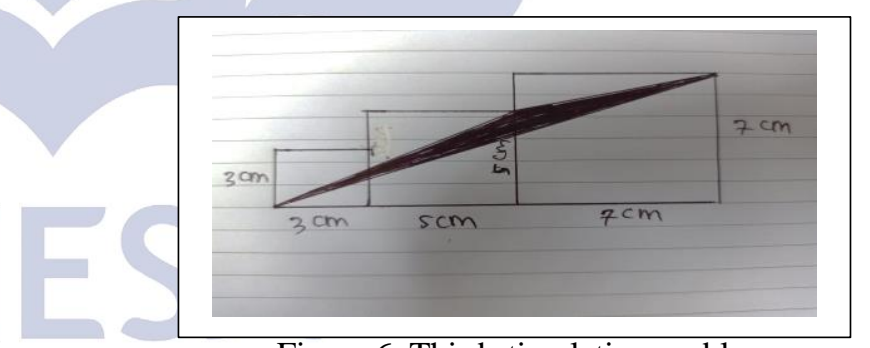

Figure 6. Third stimulation problem

$\mathrm{R}$

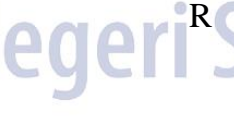

C

Now, if there are problems like that, how do you calculate the shaded area? This problem is similar to the problem before.

S2 : Oh, that means I can extend the shape to make it easier to count.

$\mathrm{R} \quad$ : Now, do you understand?

S2 : Yes, I do.

$[\mathrm{R}:$ Now, try working on this problem (open-ended test) using the way as before. What is your plan?

S2 : So, I extended the shape so that the three squares combined into a rectangle. 
R : Then, how to calculate the shaded area?

$2 \mathrm{a}\left\{\begin{array}{l}\mathrm{S} 2: \quad \begin{array}{l}\text { The area of the large rectangle minus } \\ \text { the area of the upper triangle minus the }\end{array}\end{array}\right.$ area of the bottom triangle minus the area of this additional rectangle.

R : Has this plan been thought of from the beginning when working? Or is there a change?

S2 : Yes, there is a change. Earlier the first plan that I made there was a mistake. So, I changed my plan after getting an explanation from you.

The third step is carrying out the plan. Based on Figure 3, S2 makes a mistake in the calculation. However, S2 can correct answers through interview and got the following answer.

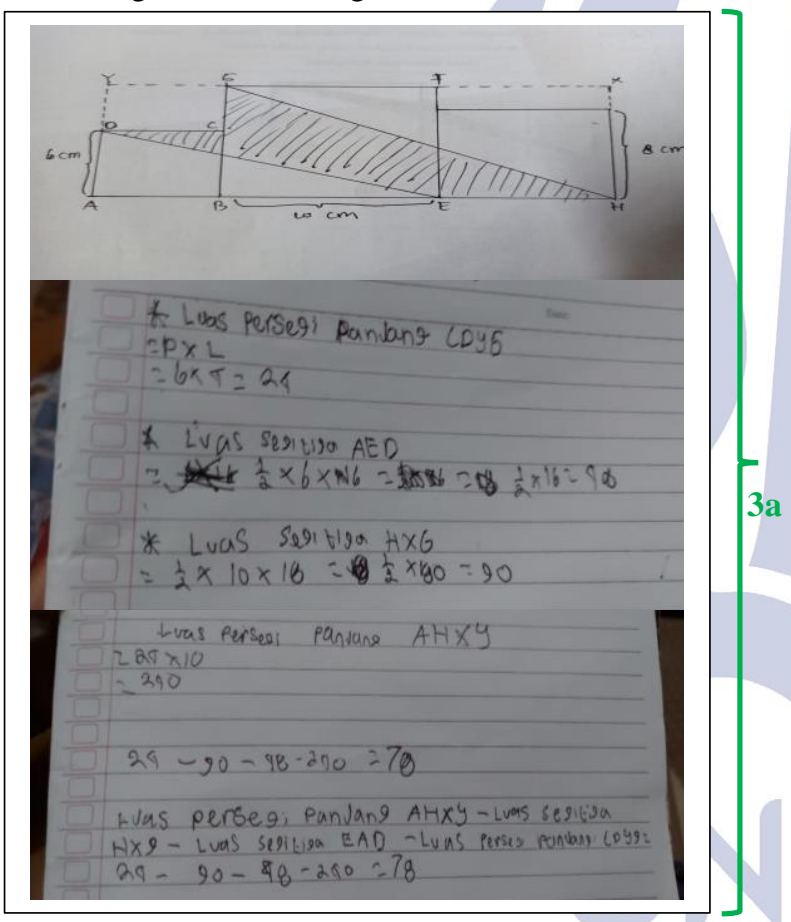

Figure 7. Results of the improved answers from S2

$\mathrm{R}$ : Can yo do it?

S2 : Yes, But I don't know my answer is correct or not.

[ $\mathrm{R}$ : Are the steps in accordance with the plan you made before?

S2 : Yes.

R : On CDYG, how did you know that the width is $4 \mathrm{~cm}$ ?

S2 : The length of BG is $10 \mathrm{~cm}$, The length of BC $6 \mathrm{~cm}$. So, The length of $\mathrm{CG}$ is $10-6=4 \mathrm{~cm}$.

$\mathrm{R}$ : Yes, you are right. Then, what is the height of AED?

S2 : $16 \mathrm{~cm}$, come from $6 \mathrm{~cm}$ plus $10 \mathrm{~cm}$.
R : On AHXY, how did you know that the width is $10 \mathrm{~cm}$ ?

S2 : The width of the AHXY rectangle is the same as the length of the large square side, that is $10 \mathrm{~cm}$.

$\mathrm{R}$ : Yes. So, what is the area of shaded region?

S2 : $78 \mathrm{~cm}^{2}$.

The fourth step is looking back. At this step, S2 can re-check the answer. S2 also believes in the answers that have been obtained. However, S2 can only work on problems using one way. This is shown in the following interview excerpt.

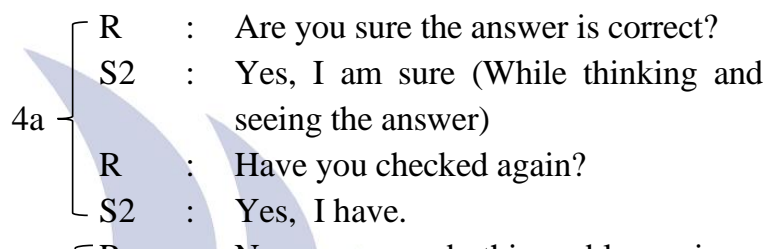

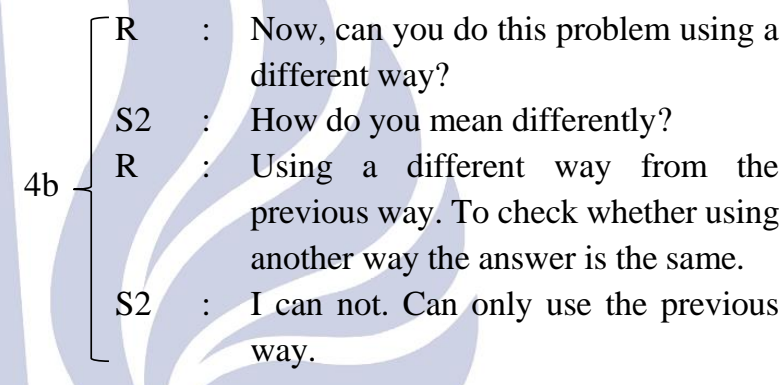

3. Profile Open-Ended Problem Solving on Low Mathematical Ability Student

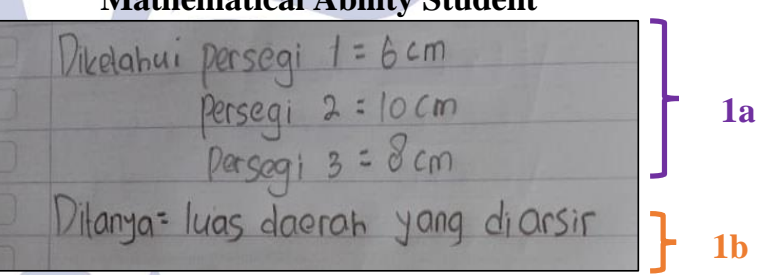

Figure 8. Results of written answers from S3

In the step of understanding the problem, S3 writes the things that are known and asked on the answer sheet as shown in Figure 8. More clearly, researchers explore information through interviews as follows.

$\mathrm{R}$ : Do you understand the problem given?

S3 : Yes. But, I can not do it.

$[\mathrm{R}:$ Please tell me what the problem is like?

1a S3 : There are three squares. The first measures $6 \mathrm{~cm}$, the second measures $10 \mathrm{~cm}$, the third measures $8 \mathrm{~cm}$.

$1 \mathrm{~b}\left\{\begin{array}{lll}\mathrm{R} & \mathrm{a} & \text { Then, what is the question? } \\ \mathrm{S} 3 & \text { : } & \text { The }\end{array}\right.$

$[\mathrm{R}$ : You can already mention known things. Well, is there still more to be 
known so that the problem can be worked on or is it enough?

S3 : I don't know.

$\mathrm{R}$ : According to you, is this problem classified as difficult, medium or easy?

S3 : I think it is difficult.

Based on the interview excerpt above, S3 can retell the problem given. However, S3 cannot show the adequacy of data from the given problem.

After the step of understanding the problem, the second step is devising a plan. S3 does not write a settlement plan on the answer sheet. For more details, researcher explore information through interviews as follows.

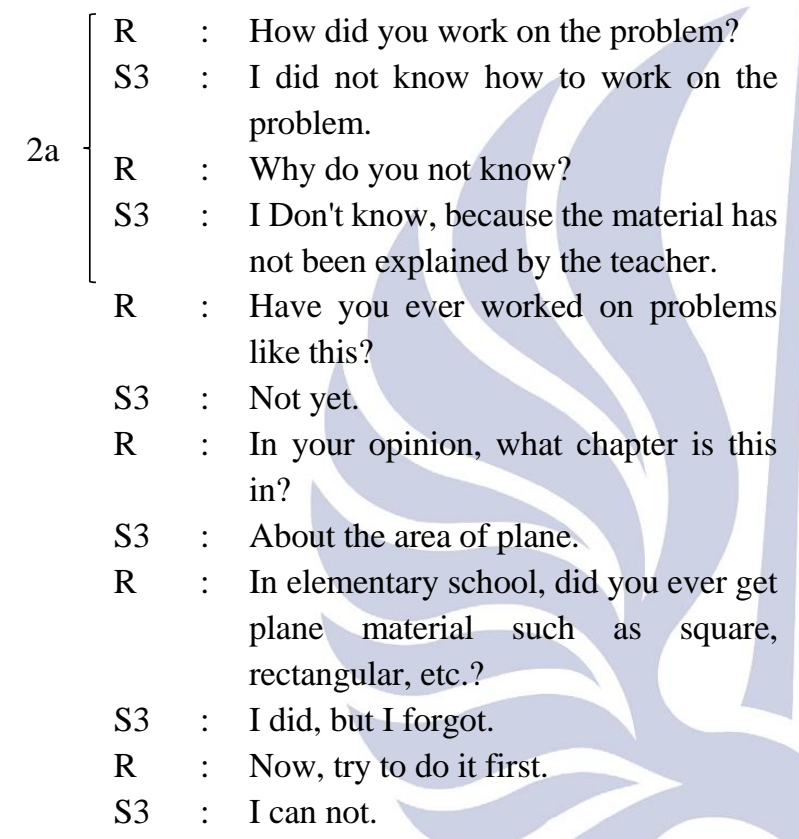

Based on interviews that have been done, S3 did not implement steps of devising a plan, carrying out the plan, and looking back.

\section{Discussion}

In the step of understanding the problem, S1 (student with high mathematical ability) have understood the problem given and can retell the problem using their own sentences. S1 mentions all the things that are known and asked. S1 also shows that the information or data presented is enough to solve the problem. At the step of devising a plan, the S1 compiles the planning steps based on the knowledge and experience already possessed. At the step of carrying out the plan, S1 carries out the plan in accordance with the first steps that have been prepared. S1 does the problem coherently. In thelooking back step, $\mathrm{S} 1$ can re-check the work done and ensure that the answer is correct. S1 can also work on problems using different strategy. Based on the description above, S1 can carry out all steps of Polya's problem solving. This is in line with the opinion of Zakaria and Yusoff (2009) which states the level of mathematical ability plays an important role in problem solving. The better the level of mathematical ability of students, the better problem solving.

In the step of understanding the problem, S2 (student with moderate mathematics ability) understands the problem that has been given. S2 also writes things that are known and asked through the illustrations that are made. At the step of devising a plan, S2 writes the plan on the answer sheet but it is not correct. S2 made a mistake in interpreting the intended shape so that it resulted in an error in the calculation that had been done. However, S2 can arrange the completion steps precisely after getting a stimulus. At the stage of carrying out the plan, S2 works on the problem according to the steps that have been prepared. In the looking back step, S2 can re-check the work that has been done but can not show other way that can be used to solve the problem.

In the step of understanding the problem, S3 (student with low mathematical ability) can retell the problem given. S3 also writes things that are known and things that are asked on the answer sheet. However, S3 cannot show the adequacy of the data provided. In addition, S3 also left three other Polya steps namely the stage of devising a plan, carrying out the plan, and looking back. These steps cannot be carried out due to lack of knowledge possessed by the student.

\section{CLOSURE}

\section{Conclusion}

Based on the results and discussion, it can be concluded as follows.

\section{Profile of Open-Ended Problem Solving on Low Mathematical Ability Student}

In the step of understanding the problem, student with high mathematical ability can mention all the things that are known and asked. Student knows that the things given to the problem are enough to work on the problem. At the step of devising a plan, student writes a plan that is used to solve problems. At the step of carrying out the plan, students has carried out calculations in accordance with the plans that has been made and explain the strategies used to solve the problem. In the looking back step, student has re-checked the results obtained. Student also works on problems in other way or strategie. Student also makes conclusions.

2. Profile of Open-Ended Problem Solving on Moderate Mathematical Ability Student

In the step of understanding the problem, student with moderate mathematical ability are able to write down all the things that are known and asked through illustrated images. Student 
knows that the things given to the problem are enough to work on the problem. At the step of devising s plan, student writes a plan that is used to solve problems but with the help of stimuli from researcher. At the step of carrying out the plan, student has carried out calculations in accordance with the plans that have been prepared and explained the strategies used to solve the problem. In the looking back step, student has rechecked the results obtained. However, student does not work on problems using other ways or strategies. Student also does not make conclusions.

3. Profile of Open-Ended Problem Solving on Low Mathematical Ability Student

In the step of understanding the problem, student with low mathematical ability can write down all the things that are known and asked. However, student cannot show the adequacy of the information provided. At the step of devising a plan, student do not make plans that are used to solve problems. At the step of carrying out the plan and looking back also cannot be done by student.

\section{Suggestion}

Based on research that has been done, researchers provide advice that teachers should train students to solve openended problems so that their abilities improve, because based on the results of research, moderate mathematical ability student are only able to work on problems one way and low mathematical ability student are unable to work on problems. Therefore, teachers need to guide students to look for other ways of solving problems, especially for students of moderate and low ability by learning in groups so that students can exchange ideas with one another so that it enriches students' knowledge.

\section{REFERENCES}

As'ari, Abdur Rahman, dkk. 2017. Buku Guru Matematika SMP/MTs Kelas VII (Edisi Revisi 2017). Jakarta: Pusat Kurikulum dan Perbukuan, Balitbang, Kemendikbud.

Emilya, Devi, dkk. 2010. Pengembangan Soal-Soal OpenEnded Materi Lingkaran Untuk Meningkatkan Penalaran Matematika Siswa Kelas VIII Sekolah Menengah Pertama Negeri 10 Palembang, (Online),

(http://ejournal.unsri.ac.id/index.php/jpm/article/ view/316/79, diakses 01 Oktober 2019).

Febriana, Catur \& Budiarto, Mega Teguh. 2013. Profil Kemampuan Siswa SMA dalam Menyelesaikan Soal Fungsi Kuadrat Berdasarkan Teori APOS
Ditinjau dari Perbedaan Kemampuan Matematika, (Online), (https://jurnalmahasiswa.unesa.ac.id/inedx.php/ mathedunesa/article/view/3876/6422, diakses 05 Oktober 2019).

Foong, Pui Yee. 2002. Using Short Open-Ended Mathematics Questions to Promote Thinking and Understanding, (Online), (http//math.unipa.it/ grim/SiFoong.PDF, diakses 8 Juli 2020).

Hudojo, Herman. 1988. Mengajar Belajar Matematika. Jakarta: P2LPTK, Dirjen Dikti, Depdikbud.

Miles \& Huberman, A. 2014. Analisis Data Kualitatif. Terjemahan Tjetjep Rohendi Rohidi. Jakarta: UI Press.

Muhsetyo, Gatot. 2009. Pembelajaran Matematika SD. Jakarta: Universitas Terbuka.

National Council of Teacher of Mathematics (NCTM). 2000. Principle and Stadikrds for School Mathematics. Reston. VA: NCTM.

OECD. 2018. PISA 2015 Results in Focus. PISA: OECD Publishing.

Ozturk, Tugba \& Guvent, Bulent. 2016. Evaluating Students'Beliefs in Problem Solving Process: A Case Study, Eurasia Journal of Mathematics, Science \& Technology Education, 12(2).

Panduan Penilaian oleh Pendidik dan Satuan Pendidikan untuk Sekolah Menengah Pertama. 2017. Kementerian Pendidikan dan Kebudayaan Direktorat Jenderal Pendidikan Dasar dan Menengah, Direktorat Pembinaan Sekolah Menengah Pertama.

Permendikbud. 2016. Peraturan Menteri Pendidikan dan Kebudayaan Nomor 21 Tahun 2016 Tentang Standar Isi Pendidikan Dasar dan Menengah.

Polya, G. 2004. How to Solve it a new aspect of mathematical method. New Jersey: Princeton University Press.

Purnamasari, P. D. 2015. Analisis Kemampuan Pemecahan Masalah Matematika Siswa Kelas XI SMK Muhammadiyah I Patuk pada Pokok Bahasan Peluang, Jurnal Pendidikan Matematika dan Sains, 1 (1), 1-7.

Shimada, S. \& Becker, J. 2007. The Significance of an Open-Ended Approach. Dalam J.P. Becker dan S. Shimada (ed) The Open-Ended Approach: A New Proposal for Teaching Mathematics. Reston, VA: NCTM.

Schoenfeld, A.H. 1985. Mathematical Problem Solving. Orlando, FL: Academic Press.

Wahyudi \& Budiono, Inawati. 2012. Pemecahan Masalah. Salatiga: Widya Sari Press. 
Zakaria, E. \& Yusoff, N. 2009. Attitudes and Problem Solving-Solving Skills in Algebra Among Malaysian Matriculation College Students. European Journal of Social Sciences. 8(2). 232245.

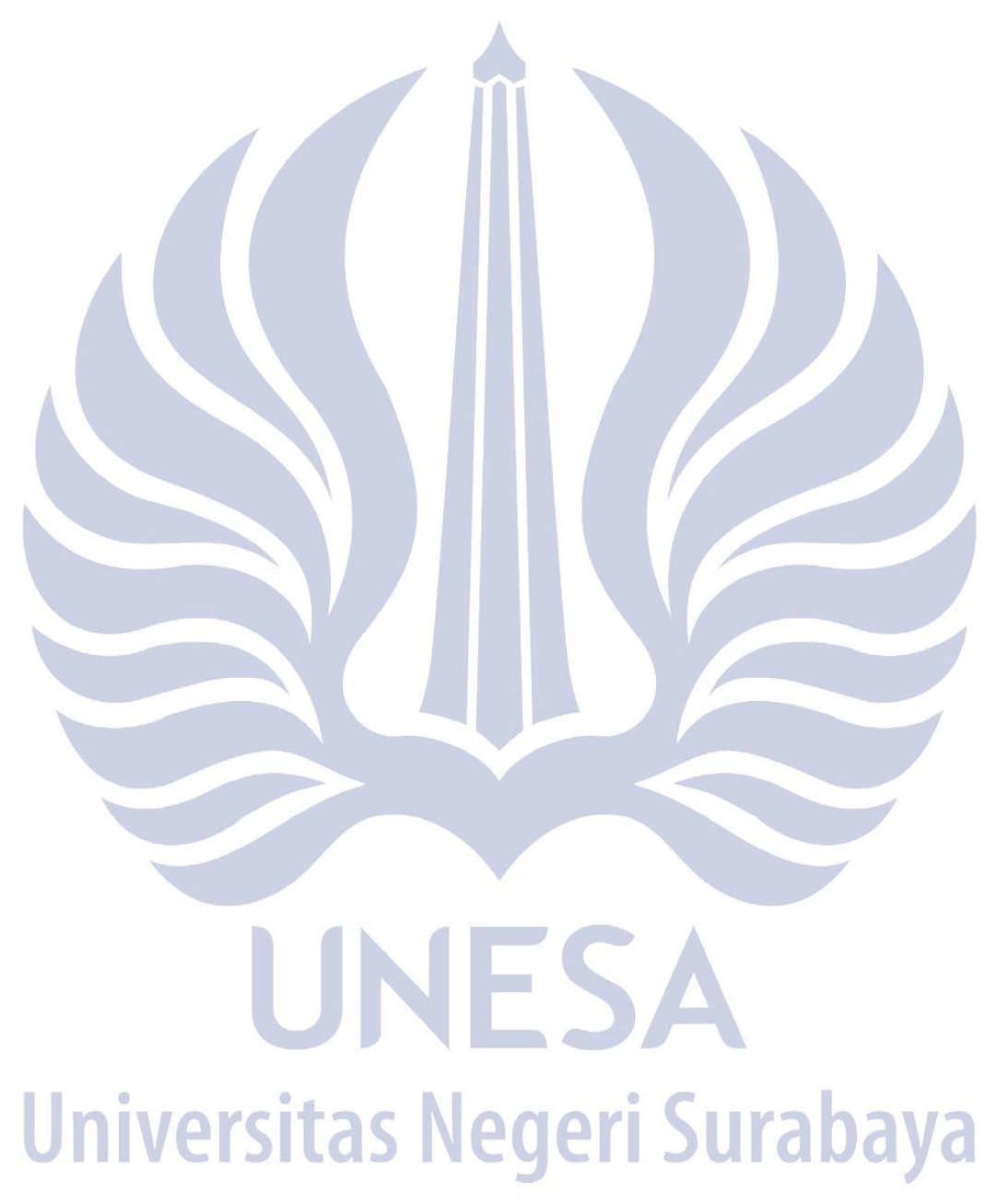

